\title{
CONTEMPORARY HEALTH PSYCHOLOGY FROM A CRITICAL PERSPECTIVE
}

\author{
UDC 159.9:61
}

\author{
Ljubiša Zlatanović \\ University of Niš, Faculty of Philosophy, Department of Psychology, Niš, Serbia
}

\begin{abstract}
Although there is a diversity of scientific trends and tendencies within health psychology, it could be said that this discipline of psychology consists of two main and clearly different approaches: the dominant approach of traditional ("mainstream") health psychology and the recently developed but growing approach of "critical" health psychology. In line with this contention, in the focus of attention of this article are the current state and the newer critical trends in theory, research and practice of contemporary health psychology. The main aims of the article are the following: (1) to present the key points of difference between these two distinct approaches to health psychology, emphasizing the central conceptual and methodological developments within critical health psychology; (2) to indicate the reasons for critical rethinking existing health psychology; and (3) to suggest that critical alternative approaches are an important contribution to the further development of contemporary health psychology as an academic discipline.
\end{abstract}

Key words: health psychology, traditional and critical approaches, psychology and health, health-related behaviour and experience.

\section{INTRODUCTION}

Health psychology has become an important discipline within contemporary applied psychology - the area of psychology in which basic theory and research are applied to the various actual problems faced by individuals in the reality of their everyday life (Bekerian and Levey 2005). Beginning from the premise of usefulness and application, it utilizes this knowledge of basic psychology in its dealing with a wide range of important psychological aspects of physical health and illness, investigating in applied research the complex relationships between the human mind and a person's physical health condition, and showing how the application of psychology can be of benefit in the health - related area of study.

Received January 4, 2017 / Accepted June 16, 2017

Corresponding author: Ljubiša Zlatanović

University of Niš, Faculty of Philosophy, Cirila i Metodija 2, 18000 Niš, Serbia

E-mail: ljubisa.zlatanovic@filfak.ni.ac.rs 
Health psychology is a relatively recent subfield within in the range of applied psychology, but its roots are old and varied. Concerned with the study of psychological processes in health, illness and healthcare it draws upon numerous relevant fields in psychology, making a bridge between the discipline of psychology and behavioural medicine - the interdisciplinary field of research and practice which integrates behavioural with biomedical scientific knowledge and techniques relevant to physical health and illness, and tries to apply this knowledge and these techniques to prevention, diagnosis, treatment and rehabilitation. In general, health psychology could be viewed as the aggregate of the specific scientific, educational and professional contributions of psychology to (1) the promotion and education in the maintenance of physical health, (2) the treatment and prevention of illness, (3) the identification of etiologic and diagnostic correlates of health, illness and related physical dysfunction, as well as to (4) the pragmatic analysis and improvement of the health policy formation (see Matarazzo 1980; Ogden 1996; Wertlieb 1987).

Although health psychology is a diverse new and rapidly expanding discipline with a variety of emphases, it is concerned with both more general and more specific health issues, mainly in the context of physical health and illness. This includes topics such as, for instance, stress, pain, cancer, sexual health, physical inactivity, adjustment to chronic illness, smoking cessation, dietary weight loss, unhealthy nutrition, alcohol and drug dependence or abuse, as well as the various questions related to utilization of health care resources. These and other topics are considered within the main areas of research in health psychology, including (1) psychological study of various aspects of relationships between the mental and physical health, (2) guidance in improvement of health trough lifestyle changes, and (3) analysis and improvement of the health care system in general (e.g. diagnostic and prescription processes, health behaviours, provider-patient interaction, and training of health care personnel (e.g. Ogden 1996; Rodham 2010; Strickland 2001).

An area of special interest in health psychology is the study of health behaviour - the study of various behavioural factors that are associated with staying healthy. In other words, it is the study of how people take care of or neglect their health, either in a preventive context or when they are ill. This area of theory, research and practice includes not only understanding the complexity of health behavior, but also predicting and changing human health behaviour. Related to this, it is important to note that the concept of health behaviour has been defined in various ways, as well as that some of these definitions limit the whole range of behaviour considered to fall under this broad concept. An example of a concise but adequate enough definition of this concept is Gochman's (1997) definition of health behaviour as "(...) overt behavioural patterns, actions and habits that relate to health maintenance, to health restoration and to health improvement" (vol.1:3). In other words, it could be said that a useful definition of health behaviour would include any activity undertaken for the purpose of preventing or detecting disease, or for improving physical health status and personal well-being. This definition includes a variety of health-related behaviours such as medical service usage, compliance with medical regimens, and self-directed health behaviour or health and lifestyles. The main focus within this area of research is the study of behaviours that influence health and the factors determining which individuals will and will not dispay such health behaviour - in other words, study of the predictors of displaying health behaviour. In addition to that study, an increasingly important related area of research is the study focused on the effectiveness of interventions, designed also in line with a certain theoretical model that leads to changes in the target 
health behaviour. In this research endeavor, a great number of studies are conducted particularly in order to assess the advantages and disadvantages of using social cognition theoretical models or approaches in the prediction, adoption, initiation, long- term maintenance and changing of health behaviour (for detailed reviews, see Blaxter 1990; Conner and Norman 2005a; Marks, Murray, Evans and Estacio 2011).

In very general terms, from its establishing as a discipline, health psychology has been influenced by different more general and more specific psychological developments in theory and research, sharing with them not only some fundamental questions and problems but also some critical tendencies and challenges. In the focus of attention of this article are some particularly important issues and challenges for the theory, research and practice in the prevailing or so-called "mainstream" health psychology developed within recent critical approaches in this psychological discipline as a reflection or an influence of various critical perspectives in contemporary psychology, which are the latest development within the hermeneutic approach. This movement in psychology includes a number of positions that became known as critical psychology or, as Brysbaert and Rastle $(2009,354)$ suggest, "rather critical psychologies, as the different positions do not see themselves as fully compatible".

\section{CRITICAL RETHINKING HEALTH PSYCHOLOGY}

\subsection{Critical approaches to health psychology: A theoretical background}

It is well-known that new scientific ideas do not come out of a vacuum; they have their own intellectual sources, or its own intellectual history, from which they have arisen. Thus, for this reason, it follows that the emergence of critical approaches to health psychology is not a surprising development. In addition to more or less strong influences of some theoretical developments within contemporary psychology such as, first and foremost, the impact of modern cognitive psychology or the so-called 'the cognitive revolution in psychology' (see e.g. Baars 1986), in recent years health psychology has also been under the influences of various critical approaches developed in psychology during the late 1990s, especially in social psychology, as well as in post-modern philosophy and in other social sciences such as sociology, anthropology and pedagogy (see more e.g. Burr 1995; Gergen 1985 and Gergen 2003, 2004; Teo 2005). Broadly speaking, a common defining feature of these critical perspectives, which tend to vary widely in their aim and scope, is a growing discontent with the current state in psychological theory and research, including also the practice in different areas of psychology, as well as a rethinking of this state or an attempt to question the status quo of psychology, and an endeavor to make its fundamental changes.

There are various kinds of critical approaches within psychology, and they all challenge many of the existing theories and practices that are common in so-called 'mainstream' psychology. Besides the radical perspectives developed earlier within psychology (during 1970s), and their strong critics focused on the positivism and reductionism of the prevailing psychology and psychiatry (see e.g. Heather 1976), the newer critical approaches are known mostly as critical psychology or as social constructionism. In short, critical psychology is the movement in psychology that criticizes mainstream psychology for failing to understand that human knowledge does not refer to an outside reality (idealism instead of realism), that scientific knowledge is not cumulative but consists of social constructions in which 
scientific statements are primarily determined by the language and the culture of the scientists, and that psychological theories and claims change the perception of people and consequently have an impact on the world in which people live (Brysbaert and Rastle 2009, 354). As an integral part of this broad critical approach in psychology, social constructionism is also a recent alternative trend within academic psychology which explicitly relates to the post-modern discourse, mainly in social psychology. It is concerned with meaning and understanding as the central feature of human activities; meaning and understanding have their beginnings in social interaction and they are specific to particular times and places. In addition, social constructionism emphasizes the linguistic and social construction of reality and personal identities, the transformation of the personal self into a state of relatedness and the move from knowledge as abstract, universal and objective to socially useful, local knowledge (e.g. Gergen 1991; Kvale 1994a). What follows from this is that most social constructionists have an uneasy relationship with the traditional essentialist idea that one of the major goals of psychology is to uncover the essential characteristics of people. In Lock's and Strong's words:

"If people fashion who they are within their varying socio-cultural traditions, then they are instrumental in creating the discourses they use to define themselves. Thus, people are selfdefining and socially constructed participants in their shared lives. There are no pre-defined entities within them that objective methods can seek to delineate but, rather, our ways of making sense to each other are constructed to yield quite different ways of being selves.

[...] In this sense, social constructionists are interested in delineating the processes that operate in the socio-cultural conduct of action to produce the discourses within which people construe themselves" (Lock and Strong 2011, 7, emphasis added).

Contemporary social constructionism also involves a loss of hegemony for formalized experimental and quantitative research methods that are associated with the naturalscience approach based on the hypothetic-deductive model, an acceptance of the open and ambiguous nature of human knowledge and diverse ways of producing such knowledge. Related to the previous point, a multi-method approach to research is strongly emphasized, including the use of qualitative methods which provide detailed descriptions and a deeper understanding of "the cultural world of intersubjective meaning" (Kvale 1994, 51), understanding phenomena (including people) in their historical and sociocultural context. Qualitative research methods are favored by the critical-hermeneutic approach in psychology, because they allow researchers to understand the complete situation they find themselves in. Thus, according to this approach, psychologists cannot pretend they are studying their subject matter in a detached way from the outside. They are not outside the phenomena that they study, but are active and responsible part of the subject matter and have to act accordingly (cf. Brysbaert and Rastle 2009).

\subsection{The emergence of critical approaches within health psychology}

There are various more or less important developments in health-related psychological theory and research that can be viewed as noticeable signs of the emerging critical health psychology. This can be illustrated with several contemporary examples. Let us mention briefly the following three examples.

One characteristic example of these developments within health psychology discipline includes Radley's social psychology of health and disease - in particular, its socio-cultural approach to the social realms and the qualities of illness experience, the understanding how 
illness can disrupt a person's daily life, and to the socio-psychological study aiming to provide new insights into processes of health and disease. The approach attempts to counter the predominant 'individualistic' emphasis of current health psychology and psychological science in general, including features such as the central significance of a strong sense of personal control and independence, and its consequences of human health and well-being (see e.g. Radley 1994, 1999).

The second recent example is Michael Hyland's critical meta-theory of health and disease - a provocative theoretical synthesis that incorporates the notions of mind, brain, body, and external environment, with a primary aim to stimulate future, theory-driven, health research programmes and clinical practice. Challenging existing conceptualizations in health psychology and in other scientific disciplines related to human health, this theoretical approach provides a new in-depth understanding of the origins of health and disease, particularly some previously unexplained medical phenomena or phenomena that are, at best, poorly understood - diseases or clinical syndromes such as, for instance, chronic fatigue syndrome, repetitive strain injury, and food intolerance (see Hyland 2011).

The third and the most important example, consistent with the critical health psychology approach, provides the above mentioned contemporary research methodological developments in qualitative approaches to psychological research, including qualitative theories and methods used in health psychology today, which began to appear, together with some important critical approaches, during the late 1980s and 1990s. Thus, many scholars speak today about "qualitative psychology' and, furthermore, about 'qualitative health psychology' (see e.g. Murray and Chamberlain 1999, Smith 2008; Willig 2008). Emphasizing the fundamental importance of language, subjective and inter-subjective experience of the (social and material) world, meaning and interpretation of human experience (in order to gain its deeper understanding), qualitative research approaches such as qualitative interviews, phenomenological and interpretative phenomenological methods of analysis, discursive and narrative forms of analysis, focus groups, and the case study approach to the study of singular entities and phenomena, all have found very fruitful applications in more recent health psychology (see e.g. Crossley 2000a; King and Horrocks 2010; Smith 2007, 2008; Smith and Osborn 2007; Willig 2008).

For example, focus groups have only recently emerged as a standard data collection technique for qualitative researchers in psychology, as qualitative research has burgeoned and become more generally accepted within the predominantly quantitative discipline of psychology (Smith 2008). However, focus groups are now a very popular and widely used method of collecting qualitative data in health psychology, especially within the fields of preventive health education and health promotion (e.g. Basch 1987), as well as in qualitative health research in general (e.g. Carey 1995; Wilkinson 1998). Informal group discussion about various important issues and the dynamic quality of group interaction are considered as the features that make focus groups particularly well suited to exploring 'sensitive' topics. Thus, for instance, the method was widely used to study issues such as sexual attitudes and behaviours, particularly in relation to HIV/AIDS (Wilkinson 2008).

As another illustrative example, let us mention also the use of interpretative phenomenological analysis in health-related studies. As a version of the phenomenological method, interpretative phenomenological analysis aims to explore the research participant's experience from his or her own perspective, recognizing that "such an exploration must necessarily implicate the researcher's own view of the world as well as the nature of the interaction between researcher and participant" (Willig 2008, 56-57). Therefore, a 
researcher's phenomenological analysis is always an interpretation of the participant's experience. An example of the use of this qualitative method in health psychology is the study aiming to explore the personal experience of chronic benign lower back pain as it is mediated by the personal meanings that sufferers attribute to it. Here, interpretative phenomenological analysis was chosen as a suitable method to study the psychological processes that determine and maintain the dynamic relationship between the patients' (participants') chronic back pain and their pain experiences characterized by high levels of distress and disability (see more Osborn and Smith 1998; for brief review, see also Willig 2008).

These and other critically-based developments have provided valuable conceptual framework for critically rethinking health psychology as a discipline. A flourishing literature in this recent approach grew out of these theoretical and research sources.

\subsection{The two main approaches to health psychology: "mainstream "and "critical" approaches}

Although there is a diversity of trends and research interests within contemporary health psychology, broadly speaking there are the two distinct and confronted approaches, or two different "voices": the dominant approach of traditional mainstream health psychology and the newly founded but growing approach of critical health psychology. It should be noted, however, that various similar terms have been used for the proposed approaches within this discipline of psychology.

Thus, these two approaches can also be described as the "scientific" (or "positivist") and the "hermeneutic" approaches, as predominantly "quantitative" and predominantly or mostly "qualitative", or as "objective" and "subjective" approaches or perspectives, existing in contemporary health psychology. Again, these two perspectives essentially reflect two major epistemological approaches to acquiring knowledge and understanding of human behaviour and experience. The first of these is the "natural science" approach that implies the study of behaviuor and experience in a manner similar to the way in which natural scientists conduct experiments to search for a single, "true" account of reality. However, human behaviour often does not fit comfortably within this model of science. For this reason, another approach is found to be more illuminating. It is the "human science" approach that explores human behaviour and experience using a variety of methods, including first of all qualitative ones. This approach, as emphasized in this article, focuses upon understanding the underlying personal meanings and the ways in which the world looks from the perspective of one individual, including also the meanings of one group or one culture (c.f. Marks, Murray, Evans and Estacio 2011). It is important to note that in the scientific literature within this field of psychology these various general terms are often used interchangeably, i.e. as synonymous descriptive terms.

As some authors in this area of research and practice have noted (e.g. Crossley 2000), mainstream health psychology tradition is a mainly American scientific enterprise, while critical health psychology approaches are more European-based and developed perspectives. The conceptual and methodological differences between the two approaches to health psychology are important and many-sided. Furthermore, as Michele Crossley (Crossley $2000,1)$ has suggested in a strong way, "these differences are quite fundamental, impacting on the very definition of what exactly the subject matter of health psychology consists of, and how such material should be studied". What follows is a focus on the two key questions: What 
are these main differences? What are the problems with mainstream health psychology and what solutions are offered by a critical approach to this health psychology?

First, at a more general level, mainstream health psychology draws heavily on a discourse of scientific progress, on a conception of research as a strictly objective scientific endeavor which builds on a discovered objective knowledge about behaviours and experiences that are related to health and illness, with the main purpose to help individuals adjust to the demands of health and illness in the conditions of contemporary society. In Crossley's words:

"Mainstream health psychological approaches rely heavily on pre-defined models of healthand illness- related behaviours. As is clear from any health psychology textbook, a multiplicity of models exists in relation to any aspect of behaviour under discussion. These models tend to consist of an amalgamation of multiple hypothetical constructs related to biological, social and psychological variables. The empirical data fed into these models is frequently derived from quantitative measures of psychological variables such as behaviours, beliefs, attitudes and perceptions, obtained through lab-based experiments, quasi-experimental designs and structured questionnaires. These measuring instruments, or tools, are designed to elicit and limit responses in accordance with the pre-defined theoretical model" (Crossley 2000, 4).

As we have noted, the basic research aim of this traditional and dominant approach is to uncover the so-called "objective truth", or the useful evidence-based "facts" about psychological or behavioural phenomena and processes related to human health and illness. The main applied aims of mainstream health psychology are twofold: (1) to predict behaviours related to health and illness through the development and empirical testing of theories and models, and (2) to control, manage or change these behaviours through the practical application of different theories and models about the main influences on the health of individual human beings. These are the basic research and practical aims which describe or define mainstream health psychology as a scientific discipline with the objective researchers and practitioners in the field of health-related behaviour and experience. In this endeavor, as pointed out, the empirical data are derived predominantly from various quantitative measures designed for the objective assessment of health behaviour and experiences.

Besides that, from the point of view of critical health psychology, there are two key tendencies within traditional health psychology that their proponents are not always willing to admit: (1) the tendency to restrict the research imagination and to reduce many important issues related to human health and illness to more instrumental or technical problems of behaviour management and control; and, on a more general level, (2) the tendency to perpetuate some of the prevalent ideologies, problems, and cultural processes and values that are embedded in contemporary Western over-individualistic and over-materialistic societies, in which individuals are responsible, governed by freely taken choices, for their own health behaviours and health in general. In other words, mainstream health psychology tends to reinforce or prevent individualism based on interests and values embedded in mass culture and, relatedly, individualization - "trend in society towards looser social relations and a greater focus by individuals on themselves than on the groups they belong to" (Brysbaert and Rastle 2009, 493).

Related to the previous point, it is particularly important to note that over-concern with personal control and responsibility for health behaviours can lead to guilt and stigmatization. Thus, Brownell warned that the "tendency to overstate the impact of personal behaviour on health" could feed the victim-blaming ethos that is already strong 
in Western societies (Brownell 1991, 303). It has been also recognized that "a large amount of the burden of disease is the product of a toxic environment that pushes people towards health-aversive behaviours", as well as that, therefore, health interventions must be "multi-leveled, not purely behavioural or educational in kind, as the evidence suggests that such approaches alone are ineffectual and too small in scale" (Marks, Murray, Evans and Estacio 2011, xi).

For this reason, critically oriented health psychologists draw upon notions of social justice and investigate how social injustices can contribute to illness. As a result, the recent community, public and, to some extent, the organizational health psychologists are paying increasing attention to collective action and efforts to change the context in which people live and work (e.g. Raphael 2003). The psychologists in these newer variants of health psychology see the assumed primary causes of illness not as something that is related solely to individual health- related choices and behaviours, but as associated more with life- and work-circumstances and relationships in society, including also broader socioeconomic and political processes. Thus, increased emphasis is being placed on issues such as social justice and the need for social transformation to ensure equity in health (e.g. Chamberlain and Murray 2009). Therefore, this work provides an important extension from a focus on individuals to explorations of people in social context - i.e. from individualistic to more collectivistic approaches to health psychology, which attempt to prevent or reduce the negative consequences of societal arrangements, injustices, power and politics. Such a collectivist approach requires health psychologists to have a broad focus and to work collaboratively with people within a community and work context in an effort to cultivate social conditions in which people can be healthy (see e.g. Campbell and Murray 2004). In this endeavor, increased emphasis is placed on relationships between individual, community and societal levels of health, including an important orientation to participation - the process by which disadvantaged people are supported in working collectively towards social inclusion (Hodgetts et al. 2010).

As noted earlier in this article, critical approaches developed within health psychology challenge many key underlying assumptions of the theories, research and applications that are common in mainstream health psychology, in a similar way as critical psychology challenges mainstream psychology in general. In addition to previously mentioned central points of difference between mainstream and critical health psychology (quantitative research methods - qualitative research methods, unhealthy and healthy behaviour - meaning of health and illness, explanation and prediction - contextuality and understanding health and illness, objectivity - subjectivity), one of the core concerns of critical health psychology is the inadequacy of the way in which mainstream health psychology has adopted a biopsychosocial model of human health. This model of health, often associated with the mentioned broad focus of the collectivist approach to health, is based on the view that health and illness are affected interactively by a complex combination of physical, psychological and social (cultural) factors (Engel 1997). Here, the focus is on the interaction between health and body, and there is an important acceptance of the range of individual differences in personality and socio-cultural conditions which can affect human health (Forshaw 2002).

Developed during the latter part of the twentieth century as a critique of the traditional "biomedical model", the biopsychosocial model is useful for highlighting important links between individual, relational and societal factors or determinants in health and illness. In addition, this perspective also situates individuals and groups within a broader set of socio-political relationships that shape their everyday lives, including their health and 
illness. The model draws on "system theory" to postulate the dynamic interactions across various levels of human life that span the biochemical and socio-political domains (Hodgetts et al. 2010). However, although the biopsychosocial model of health was welcomed and influential in mainstream health psychology as a useful conceptual framework for integrating the person into his or her environment (Whitbourne 2007), the model has been subject to various criticisms. Thus, for instance, as Cooper et al. $(1996,4)$ point out, this model is often presented as a "multiple, rather than integrated, explanatory framework" in which "biological, social and psychological factors co-exist in a seemingly fragmented way".

Broadly speaking, it seems that the biopsychosocial model still equates the individual with personal responsibility for health and health-related beliefs and choices, and simply adds some variables such as stress to the Western traditional purely "medical" ("biomedical") approach to health and health care. According to Jane Ogden (1997), of particular importance is the failure of this model of health to explain just how biological, psychological and social factors actually impact human health. This is an important point because it indicates in general that bio-medical mind-body dualism is to a large extent retained in this alternative model which values a more holistic approach. Namely, mind, body and society are perceived here as separate entities which, although interacting with each other, remain fundamentally particular parts in this model of health (cf. Crossley 2000; Ogden 1996). Related to these points, instead of the fragmentary conception, a critical approach emphasizes the need for a more integrated approach - a perspective which enables health psychologists to develop a deeper understanding of both the psychological dimensions of human experiences of health and illness and the socio-cultural dimensions of such experiences. As we have noted, by attempting to emulate a natural scientific way of investigation mainstream health psychology fails to appreciate these crucial elements of human experience. By contrast, a deeper understanding of such experiences (rather than controlling health-related behaviours), including an appreciation and interpretation of the unique order of meaning in relation to human experiences of health and illness is one of the major tasks and aims of critical health psychology (Crossley 2000; see Chapter 1).

\section{CONCLUSION}

Health psychology is a relatively recent interdisciplinary field of inquiry within psychology concerned with the study of psychological processes, characteristics and behavioural factors that are associated with human physical health, illness and healthcare. In addition to the influences of some general theoretical developments within contemporary psychology such as the overwhelming impact of modern cognitive psychology, health psychology has been also under the influence of various recent critical approaches developed in psychology and related scientific disciplines. Thus, as we have noted, there are basically the two distinct and mostly confronted approaches within contemporary health psychology: the dominant approach of traditional mainstream health psychology and the growing approach of recently developed critical health psychology. In this article it is emphasized that these two perspectives reflect two major epistemological approaches to acquiring knowledge about human behaviour and experience: the "natural science" approach and the "human science" approach.

In this article it is strongly suggested that critical health psychology is important on a number of inter-related theoretical, research and practical levels. It is our opinion that the 
critical views of the field of health psychology provide a new horizon for this rapidly expanding discipline: the valuable ways in which contemporary health psychology could be rethought and placed within its more broad or more global context - within its sociocultural, economic and political contexts. These critical perspectives invite mainstream health psychologists to engage in an active critical dialogue, encouraging them to take into account the alternative theoretical and methodological ways of approaching this rich and vital field of psychology. This means that such approaches underline the need for critical for critical rethinking traditional health psychology - its fundamental and specific issues and topics in theory, research and application of psychological knowledge.

In general, it could be said that critical health psychology is one which challenges theoretical models (e.g. cognitive oriented and biopsychosocial models), research (the predominant use of quantitative methods and statistical forms of analysis) and practices (e.g. health promotion focused very narrowly on cognitive processes and individual behaviour change) that are common in mainstream health psychology. At the same time, it is one which provides a valuable step towards the goal of improving the field of health psychology and its overall psychological understanding of health-related behaviour and experience. In addition, as thought-provoking and challenging, critical health psychological approaches can play a potentially significant role in the future of this discipline of psychology. As such, they are in sum, a welcome conceptual development which deserves its important place within contemporary health psychology as a discipline of psychological science with strong individualistic and rationalistic roots.

\section{REFERENCES}

Baars, B. J. The Cognitive Revolution in Psychology. New York: Guilford Press, 1986.

Basch, C. E. "Focus-group Interviews: An Underutilized Research Technique for Improving Theory and Practice in Health Education." Health Education Quarterly 154 (1987): 411-448.

Bekerian, D. A., and A. B. Levey. Applied Psychology: Putting Theory into Practice. New York: Oxford University Press, 2005.

Blaxter, M. Health and Lifestyles. London: Tavistock, 1990.

Brownell, K. "Personal Responsibility and Control Over Our Bodies: When Expectation Exceeds Reality." Health Psychology 10 (1991): 303-310.

Brysbaert, M., and K. Rastle. Historical and Conceptual Issues in Psychology. Harlow: Pearson Education Limited, 2009.

Burr, V. An Introduction to Social Constructionism. London: Routledge, 1995

Campbell, C., and M. Murray. "Community Health Psychology: Promoting Analysis and Action for Social Change." Journal of Health Psychology 9 (2004): 187-195.

Carey, M. A. (Ed.) Special Issue: Issues and Applications of Focus Groups. Qualitative Health Research 5, 4 (1995).

Chamberlain, K.., and M. Murray. "Critical Health Psychology." In Critical Psychology: An Introduction (2 ed.), edited by D. Fox, I. Prilleltensky and S. Austen, 144-159. London: Sage Publications, 2009.

Conner, M., and P. Norman. "Predicting Health Behaviour: A Social Cognition Approach." In Predicting Health Behaviour: Research and Practice with Social Cognition Models ( $2^{\text {nd }}$ ed.), edited by M. Conner and P. Norman, 1-28. Maidenhead: Open University Press, 2005.

Conner, M., and P. Norman, eds. Predicting Health Behaviour: Research and Practice with Social Cognition Models ( $2^{\text {nd }}$ ed.). Maidenhead: Open University Press, 2005a.

Cooper, N., C. Stevenson, and G. Hall. "The Biopsychosocial Model.” In Integrating Perspectives on Health, edited by N. Cooper, C. Stevenson, and G. Hall, 1-17. Buckingham: Open University Press.

Crossley, M. L. Rethinking Health Psychology. Buckingham: Open University Press, 2000.

Crossley, M. L. Introducing Narrative Psychology: Self, Trauma and the Construction of Meaning. Buckingham: Open University Press, 2000a.

Engel, G. L. "The Need for a New Medical Model: A Challenge For Biomedicine." Science 196 (1977): 129-136.

Forshaw, M. Essential Health Psychology. London: Arnold, 2002. 
Gergen, K. J. “The Social Constructionist Movement in Modern Psychology.” American Psychologist 40 (1985): $266-275$.

Gergen, K. J. The Saturated Self. New York: Basic Books, 1991

Gergen, K. J. and M. Gergen. Social Construction: Entering the Dialogue. Shagrin Falls: Taos Institute Publications, 2004.

Gergen, M. and K. J. Gergen, eds. Social Construction: A Reader. London: Sage Publications, 2003.

Gochman, D. S., ed. Handbook of Health Behaviour Research. New York: Plenum, 1997.

Heather, N. Radical Perspectives in Psychology. London: Methuen, 1976.

Hodgetts, D., N. Drew, C. Sonn, O. Stolte, L. Waimarie, and C. Curtis. Social Psychology and Everyday Life. New York: Palgrave Macmillan, 2010

Hyland, M. E. The Origins of Health and Disease. Cambridge: Cambridge University Press, 2011.

Kaptein, A., and J. Weinman, eds. Health Psychology. BPS Blackwell: Oxford University Press, 2004.

King, N., and C. Horrocs. Interviews in Qualitative Research. London: Sage Publications, 2010.

Kvale, S. "Introduction: From the Archaeology of the Psyche to the Architecture of Cultural Landscapes." In Psychology and Postmodernism, edited by S. Kvale, 1-17. London: Sage Publications, 1994.

Kvale, S. "Postmodern Psychology: A Contradiction in Terms?" In Psychology and Postmodernism, edited by S. Kvale, 31-58. London: Sage Publications, 1994a.

Lock, A., and T. Strong. Social Constructionism: Sources and Stirrings in Theory and Practice. Cambridge: Cambridge University Press, 2011.

Marks, D. F., M. Murray, B. Evans, and E. V. Estacio. Health Psychology: Theory, Research and Practice ( $3^{\text {rd }}$ ed.). London: Sage Publications, 2011.

Matarazzo, J. D. "Behavioural Health and Behavioural Medicine: Frontiers for a New Health Psychology." American Psychologist 35 (1980): 807-817.

Murray, M., and K. Chamberlain, eds. Qualitative Health Psychology: Theories and Methods. London: Sage Publications, 1999

Norman, P., and M. Conner. "Prediction and Changing Health Behaviour: Future Directions." In Predicting Health Behaviour: Research and Practice with Social Cognition Models ( $2^{\text {nd }}$ ed.), edited by M. Conner and P. Norman, 324-373. Maidenhead: Open University Press, 2005.

Ogden, J. Health Psychology. Buckingham: Open University Press, 1996.

Ogden, J. "The Rhetoric and Reality of Psychosocial Theories: A Challenge to Biomedicine." Journal of Health Psychology 2 (1997): 21-29.

Osborn, M., and J. A. Smith. "The Personal Experience of Chronic Benign Lower Back Pain: An Interpretative Phenomenological Analysis.” British Journal of Health Psychology 3 (1998): 65-83.

Radley, A. "Social Realms and the Qualities of Illness Experience." In Qualitative Health Psychology: Theories and Methods, edited by M. Murray and K. Chamberlain, 16-30. London: Sage Publications, 1999.

Raphael, D. "Toward the Future: Policy and Community Actions to Promote Population Health." In Health and Social Justice: Politics, Ideology and Inequity in the Distribution of Disease, edited by R. Hofrichter, 453468. San Francisco: Josey-Bass; Wiley, 2003

Rodham, K. Health Psychology. Houndmills: Palgrave Macmillan, 2010.

Smith, J. A., ed. Qualitative Psychology: A Practical Guide to Research Methods (2 ${ }^{\text {nd }}$ ed.). London: Sage Publications, 2008.

Smith, J. A. "Hermeneutics, Human Sciences and Health: Linking Theory and Practice." International Journal of Qualitative Studies on Health \& Well-being 2 (2007): 3-11.

Smith, J. A., and M. Osborn. "Pain as an Assault on the Self: An Interpretative Phenomenological Analysis." Psychology and Health 22 (2007): 517-534.

Strickland, B. R., ed. The Gale Encyclopedia of Psychology (2 ${ }^{\text {nd }}$ ed.). Fermington Hills: Gale Group, 2001.

Teo, T. The Critique of Psychology: From Kant to Postcolonial Theory. New York: Springer Science + Business Media, Inc., 2005

Wertlieb, D. L. "Health Psychology". In Concise Encyclopedia of Psychology, edited by R. J. Corsini, 490. New York: Wiley, 1987.

Willig, C. Introducing Qualitative Research in Psychology ( $2^{\text {nd }}$ ed.). Maidenhead: Open University Press; McGrawHill Education.

Wilkinson, S. "Focus Groups in Health Research: Exploring the Meanings of Health and Illness." Journal of Health Psychology 3, 3 (1998): 65-83.

Wilkinson, S. "Focus Groups." In Qualitative Psychology: A Practical Guide to Research Methods ( $2^{\text {nd }}$ ed.), edited by J. A. Smith, 186-207. London: Sage Publications, 2008. 


\section{SAVREMENA ZDRAVSTVENA PSIHOLOGIJA IZ KRITIČKE PERSPEKTIVE}

Iako u zdravstvenoj psihologiji postoji raznolikost naučnih trendova i tendencija, moglo bi se reći da se ova disciplina psihologije sastoji iz dva glavna i jasno različita pristupa: dominantnog pristupa tradicionalne ("mainstream") zdravstvene psihologije i u novije vreme razvijenog ali rastučeg pristupa "kriticke" zdravstvene psihologije. U skladu sa ovom tvrdnjom, u fokusu paznje ovog rada su postojeće stanje $i$ noviji kritički trendovi $u$ teoriji, istrazivanju $i$ praksi savremene zdravstvene psihologije. Glavni ciljevi rada su sledeci: (1) da izlozi ključne tačke razlike izmedju ta dva posebna pristupa zdravstvenoj psihologiji, naglašavajući središnje konceptualne i metodološke razvoje u kritičkoj zdravstvenoj psihologiji; (2) da ukaže na razloge za kritičko preispitivanje postojeće zdravsvene psihologije; $i$ (3) da sugeriše da su kritički alternativni pristupi važan doprinos daljem razvoju savremene zdravstvene psihologije kao akademske discipline.

Ključne reči: zdravstvena psihologija, tradicionalni i kritički pristupi, psihologija i zdravlje ponašanje i iskustvo u vezi sa zdravljem. 